\title{
Pengaruh Pendidikan Kesehatan dengan Whatsapp Tentang Imunisasi DPT (Difteri, Pertusis dan Tetanus) dan Kipi (Kejadian Ikutan Pasca Imunisasi) Terhadap Pengetahuan dan Sikap Ibu
}

\author{
Neneng Gia Defilza*, Meri Neherta, Deswita \\ Fakultas Keperawatan, Universitas Andalas \\ *Correspondence email: nenenggiadefilza@gmail.com
}

\begin{abstract}
Abstrak. Cakupan imunisasi DPT menurun lebih dari 35\% pada bulan Mei 2020 dibandingkan dengan periode waktu yang sama pada tahun sebelumnya. Pengetahuan ibu tentang imunisasi DPT dan KIPI berperan penting dalam menentukan keberhasilan pelaksanaan imunisasi. Pada saat pandemi Covid-19 semua aktivitas masyarakat dibatasi. Namun promosi kesehatan mengenai imunisasi pada bayi harus tetap dilaksanakan untuk meningkatkan pengetahuan dan kesadaran orang tua membawa anaknya untuk di imunisasi. Penelitian ini bertujuan untuk melihat pengaruh pendidikan kesehatan dengan menggunakan media WhatsApp terhadap pengetahuan dan sikap ibu tentang imunisasi DPT dan KIPI. Penelitian menggunakan desain quasi eksperimen pretest posttest control. Sampel berjumlah 64 responden terdiri dari 32 orang kelompok intervensi dan 32 orang kelompok kontrol. Pengambilan sampel dengan simple random sampling. Instrument yang digunakan adalah kuesioner yang disediakan dalam bentuk google form. Hasil penelitian menunjukkan terdapat pengaruh yang bermakna pendidikan kesehatan terhadap pengetahuan $(\mathrm{p}$ value $=0,000)$ dan sikap $(\mathrm{p}$ value $=0,000)$ responden pada kelompok intervensi. Namun tidak terdapat pengaruh pada kelompok kontrol, pengetahuan ( $\mathrm{p}$ value $=0,184$ ) dan sikap ( $\mathrm{p}$ value $=0,325$ ). Saran untuk tim promosi kesehatan agar tetap memberikan promosi kesehatan pada masa pandemi dengan menggunakan media whatsapp dan dilanjutkan diskusi melalui videocall. Sehingga promosi tetap dapat dilaksanakan tanpa harus mengumpulkan responden.
\end{abstract}

Kata kunci: Pendidikan kesehatan; WhatsApp; Imunisasi DPT; penanganan KIPI

\begin{abstract}
Immunization coverage may decrease by more than 35\% in May 2020 compared to the same time period in the previous year. Mother's knowledge about DPT immunization and KIPI plays an important role in determining the success of immunization implementation. During the Covid-19 pandemic, all public activities were restricted. However, health promotion in infants must still be implemented to increase the knowledge and awareness of parents bringing their children to do it. This study aims to see the effect of health education using WhatsApp on the knowledge and attitudes of mothers about DPT immunizations and KIPI. The study used a quasi-experimental pretest - posttest control design. The sample consisted of 64 respondents consisting of 32 people in the intervention group and 32 people in the control group. Sampling by simple random sampling. The instrument used was questionnaire provided in the form of google form. The results showed that there was a significant effect of health education on knowledge $(p$ value $=0.000)$ and attitudes $(p$ value $=0.000)$ of respondents in the intervention group. However, there was no effect on the control group, knowledge ( $p$ value $=0.184)$ and attitude $(p$ value $=0.325)$ of respondents. Suggestions for the health promotion team to continue to provide health promotion during the pandemic by using whatsapp media. So that the promotion can still be carried out without having to collect respondents.
\end{abstract}

Keywords: Health education; WhatsApp; DPT immunization; treatment of KIPI

\section{PENDAHULUAN}

Saat ini seluruh dunia termasuk Indonesia sedang menghadapi wabah Coronavirus Infection Disease 2019 (COVID-19) yang merupakan penyakit infeksi baru disebabkan oleh Severe Acute Respiratory Syndrome Coronavirus 2 (SARS-CoV-2). Di tengah pandemi COVID-19 pelayanan kesehatan terbebani, terfokus pada pencegahan transmisi serta penanganan kasus COVID19, ditambah penerapan sistem pembatasan sosial berskala besar (PSBB) diberbagai daerah, menyebabkan pelayanan kesehatan rutin seperti imunisasi menjadi terganggu (Kemenkes RI, 2020). Hal ini terlihat dari cakupan imunisasi yang menurun. Terutama pada imunisasi DPT berkurang lebih dari 35\% pada bulan Mei 2020 dibandingkan dengan periode waktu yang sama pada tahun sebelumnya (Kemenkes RI, 2020).
Tercapainya suatu indikator imunisasi tidak terlepas dari keterlibatan orang tua terutama ibu selaku pengambil keputusan dalam kesehatan anak (Hockenberry, 2019). Orang tua terkadang menolak membawa anaknya untuk memperoleh imunisasi DPT dikarenakan anak mengalami efek samping setelah mendapatkan imunisasi DPT atau yang dikenal dengan KIPI (kejadian ikutan paska imunisasi) (Verulava et al., 2019). Anak yang mendapat imunisasi DPT sering mengalami masalah kesehatan seperti demam dan bengkak pada area suntikan sehingga menyebabkan bayi menjadi rewel. Kondisi tersebut membuat orang tua menjadi khawatir, sehingga memilih untuk tidak melanjutkan pemberian imunisasi DPT (Kemenkes RI, 2018).

Disamping adanya KIPI, Ada beberapa faktor lain yang mempengaruhi keputusan orang tua dalam 
memberikan imunisasi pada bayinya, salah satunya faktor pengetahuan orang tua tentang imunisasi (Kemenkes RI, 2020). Orang tua yang memiliki pengetahuan yang baik akan mampu memastikan bayinya mendapatkan imunisasi DPT dan memberikan penatalaksanaan yang efektif ketika efek samping imunisasi DPT muncul (Lim et al., 2016). Namun orang tua yang tidak memiliki pemahaman tentang DPT akan menganggap DPT menyebabkan bayi mereka sakit, sehingga mereka lebih memilih untuk tidak memberikan imunisasi atau tidak menuntaskan pemberian imunisasi DPT (Azreena et al., 2018).

Beberapa penelitian sebelumnya menunjukkan adanya relevansi antara cakupan imunisasi dan pengetahuan (Yustanta dan Ikhrima, 2021; Sari et al., 2016). Hal Ini menunjukkan bahwa intervensi pendidikan diperlukan untuk meningkatkan penerimaan masyarakat terutama ibu bayi terhadap imunisasi bayi.

Pada saat pandemi Covid-19 semua aktivitas masyarakat dibatasi dan harus menerapkan social distancing dan juga physical distancing. Akan tetapi promosi kesehatan mengenai imunisasi pada bayi harus tetap dilaksanakan untuk meningkatkan pengetahuan dan kesadaran orang tua dalam membawa anaknya untuk di imunisasi. Dengan demikian banyak cara yang bisa dilakukan untuk tetap memberikan pelayanan promosi kesehatan dengan menggunakan sistem daring (dalam jaringan). Daring ialah metode belajar yang menggunakan model interaktif berbasis internet dan learning manajemen system (LMS) salah satunya adalah aplikasi WhatsApp. Menurut penelitian yang dilakukan oleh Mulyani dan Subandi (2020) pendidikan kesehatan yang dilakukan melalui grup WhatsApp efektif untuk meningkatkan pengetahuan ibu. Hal yang sama juga dikemukakan oleh Yuniarti (2020) dan Pereira, et al (2020) bahwa WhatsApp membuat Pendidikan kesehatan menjadi lebih efektif karena banyaknya fitur-fitur pendukung saat berlangsungnya Pendidikan kesehatan online di tengah pandemi Covid-19.

Provinsi Jambi termasuk kedalam 13 provinsi dengan cakupan Imunisasi terendah pada tahun 2020 yakni sebesar $86,4 \%$ dari target nasional yakni $95 \%$ (Kemenkes RI, 2021). Kota Sungai Penuh merupakan salah satu kota yang berada di Provinsi Jambi dengan cakupan imunisasi rendah. Data Dinas Kesehatan Kota Sungai Penuh menunjukkan bahwa rata-rata angka cakupan imunisasi DPT untuk tahun 2020 adalah 93,3\%. Angka tersebut hampir mencapai target nasional tahun 2020 sebesar 95\%. Walaupun demikian, diantara Puskesmas yang berada dibawah Dinas Kesehatan Sungai Penuh terdapat 2 puskesmas yang belum memenuhi capaian target nasional yaitu Puskesmas Koto Lolo dan Puskesmas Sungai Liuk. Angka capaian puskesmas tersebut secara berturut-turut yaitu 88,3\% dan 87,0\% (Dinas Kesehatan Kota Sungai Penuh, 2021).
Upaya pihak puskesmas untuk meningkatkan cakupan imunisasi adalah dengan melakukan promosi kesehatan melalui poster yang ditempelkan didinding dan metode ceramah pada program Posyandu. Saat ini promosi kesehatan tertunda karena adanya kebijakan pembatasan kegiatan kelompok masyarakat (PKKM) di daerah setempat selama masa pandemi dan posyandu diberhentikan sementara. Untuk itu peneliti bermaksud menggunakan media WhatsApp dalam meningkatkan pengetahuan, sikap ibu tentang imunisasi.

\section{METODE}

Penelitian ini menggunakan desain penelitian quasi eksperimen pretest-posttest control desain. Penelitian dilakukan di wilayah kerja Puskesmas Sungai Liuk Kota Sungai Penuh Provinsi Jambi. Sampel penelitian ini adalah ibu yang memiliki bayi usia 1-4 bulan berjumlah 64 responden terdiri dari 32 orang kelompok intervensi dan 32 orang kelompok kontrol. Teknik pengambilan sampel yaitu dengan cara simple random sampling. Kelompok intervensi diberi perlakuan Pendidikan kesehatan tentang imunisasi DPT dan KIPI dengan media WhatsApp yang terdiri dari 1 sesi dalam satu hari selama tiga hari dalam satu minggu. Instrument yang digunakan adalah kuesioner yang disediakan dalam bentuk google form dan dilakukan uji validitas dan realibilitas. Data yang diperoleh dalam penelitian dianalisis secara komputerisasi menggunakan aplikasi SPSS. Penelitian ini telah mendapatkan persetujuan dari Komisi Etik RSUP Dr. M. Djamil Padang No : 226/KEPK/2021.

\section{HASIL DAN PEMBAHASAN Karakteristik Responden}

Tabel 1. Distribusi frekuensi karakteristik responden pada kelompok intervensi $(n=32)$ dan kelompok kontrol $(n=32)$ berdasarkan usia responden, pendidikan responden, pekerjaan responden dan usia bayi responden

\begin{tabular}{|c|c|c|c|c|c|}
\hline \multirow{2}{*}{$\begin{array}{c}\text { Karakteristik } \\
\text { Responden }\end{array}$} & \multirow{2}{*}{ Kategori } & \multicolumn{2}{|c|}{ Intervensi } & \multicolumn{2}{|c|}{ Kontrol } \\
\hline & & $\mathbf{N}$ & $\%$ & $\mathbf{n}$ & $\%$ \\
\hline \multirow{2}{*}{ Umur ibu } & $17-25$ & 14 & 43,7 & 18 & 56,2 \\
\hline & $26-40$ & 18 & 56,1 & 14 & 43,8 \\
\hline \multirow[t]{2}{*}{ Pendidikan } & Sekolah Menengah & 25 & 71,9 & 15 & 46,9 \\
\hline & Perguruan Tinggi & 9 & 15,6 & 17 & 53,1 \\
\hline \multirow[t]{2}{*}{ Pekerjaan } & Bekerja & 11 & 31,9 & 14 & 43,7 \\
\hline & Tidak Bekerja & 21 & 65,6 & 18 & 56,3 \\
\hline \multirow[t]{2}{*}{ Usia Bayi } & $1-2$ bulan & 20 & 62,5 & 5 & 15,7 \\
\hline & $3-4$ bulan & 12 & 36 & 27 & 83,14 \\
\hline
\end{tabular}

Tabel 1 menunjukkan bahwa sebagian besar responden yang berada pada kelompok intervensi memiliki usia dalam rentang 26-40 tahun (56,1\%), pendidikan Sekolah Menengah (71,9\%), dan tidak bekerja $(65,6 \%)$. 


\section{Analisa Univariat}

TabeL 2. Rata - rata pengetahuan dan sikap responden tentang imunisasi DPT dan KIPI sebelum dan setelah diberikan intervensi pada kelompok intervensi $(n=32)$ dan kelompok kontrol $(\mathrm{n}=32)$

\begin{tabular}{lcccccc}
\hline \multirow{2}{*}{ Variabel } & \multicolumn{3}{c}{ Intervensi } & \multicolumn{3}{c}{ Kontrol } \\
\cline { 2 - 7 } & Mean & Median & SD & Mean & Median & SD \\
\hline Pengetahuan & & & & & & \\
Pretest & 6,16 & 6,00 & 2,065 & 7,16 & 7,00 & 1,648 \\
Posttest & 8,97 & 9,00 & 0,822 & 7,06 & 7,00 & 1,564 \\
\hline Sikap & & & & & & \\
Pretest & 31,06 & 31,00 & 4,428 & 31,06 & 31,00 & 4,428 \\
Posttest & 36,03 & 36,00 & 1,823 & 30,97 & 30,50 & 4,284 \\
\hline
\end{tabular}

Tabel 2 menunjukkan rata - rata pengetahuan pada kelompok intervensi sebelum diberikan Pendidikan kesehatan 6,16 dengan standart deviasi 2,065. Setelah diberikan intervensi 8,97 dengan standart deviasi 0,822. Rata - rata sikap pada kelompok intervensi sebelum diberikan intervensi yaitu 31,06 dengan standart deviasi 4,428 dan setelah diberikan intervensi 36,03 dengan standart deviasi 1,823. Pada kelompok kontrol rata - rata pengetahuan sebelum diberikan Pendidikan kesehatan 7,16 dengan standart deviasi 1,648. Setelah diberikan intervensi 7,06 dengan standart deviasi 1,564. Rata rata sikap pada kelompok kontrol sebelum diberikan intervensi yaitu 31,06 dengan standart deviasi 4,428 dan setelah diberikan intervensi 30,97 dengan standart deviasi 4,284.

\section{Analisa Bivariat}

TabeL 3. Pengaruh Pendidikan kesehatan tentang imunisasi DPT dan KIPI terhadap pengetahuan dan sikap responden pada kelompok intervensi $(\mathrm{n}=32)$ dan kelompok kontrol

\begin{tabular}{|c|c|c|}
\hline Variabel & Mean & p value \\
\hline \multicolumn{3}{|l|}{ Pengetahuan } \\
\hline \multicolumn{3}{|c|}{ Kelompok intervensi } \\
\hline $\begin{array}{ll}\text { - } & \text { Pretest } \\
\text { - } & \text { Posttest }\end{array}$ & $\begin{array}{l}6,16 \\
8,97\end{array}$ & 0,000 \\
\hline \multicolumn{3}{|l|}{ Kelompok kontrol } \\
\hline $\begin{array}{ll}\text { - } & \text { Pretest } \\
\text { - } & \text { Posttest } \\
\end{array}$ & $\begin{array}{l}7,16 \\
7,06 \\
\end{array}$ & 0,184 \\
\hline \multicolumn{3}{|c|}{ Sikap } \\
\hline \multicolumn{3}{|c|}{ Kelompok intervensi } \\
\hline $\begin{array}{ll}\text { - } & \text { Pretest } \\
\text { - } & \text { Posttest }\end{array}$ & $\begin{array}{l}31,06 \\
36,03 \\
\end{array}$ & 0,000 \\
\hline \multicolumn{3}{|l|}{ Kelompok kontrol } \\
\hline $\begin{array}{ll}\text { - } & \text { Pretest } \\
\text { - } & \text { Posttest } \\
\end{array}$ & $\begin{array}{l}31,06 \\
30,97 \\
\end{array}$ & 0,325 \\
\hline
\end{tabular}

Tabel 3 menjelaskan bahwa hasil uji statistik pada kelompok intervensi didapatkan pada variabel pengetahuan $\mathrm{p}$ value $0,000(\mathrm{p}<0,05)$ dan pada variable sikap didapatkan $\mathrm{p}$ value $0,000(\mathrm{p}<0,05)$. Ini berarti ada pengaruh sebelum dan sesudah diberikan Pendidikan kesehatan terhadap pengetahuan dan sikap responden pada kelompok intervensi. Pada kelompok kontrol pada variabel pengetahuan $\mathrm{p}$ value $0,184(\mathrm{p}>0,05)$ dan pada variabel sikap $p$ value $0,325(p>0,05)$ yang berarti tidak ada pengaruh sebelum dan sesudah diberi intervensi terhadap pengetahuan, sikap dan tindakan responden pada kelompok kontrol.

\section{Pembahasan \\ Analisa Univariat}

Hasil penelitian tabel 2 menunjukkan adanya perbedaan rata-rata pengetahuan antara kelompok intervensi dan kelompok kontrol sebelum diberikan intervensi. Rata - rata pengetahuan responden pre test pada kelompok kontrol $(7,16)$ lebih tinggi dibandingkan pada kelompok intervensi $(6,16)$. Hal ini jika dilihat dari karakteristik pendidikan responden pada kelompok kontrol lebih dari separuh merupakan tamatan perguruan tinggi, sedangkan pada kelompok intervensi separuh responden merupakan tamatan Sekolah Menengah Atas (SMA). Menurut Konwea, et al (2018) penelitiannya menjelaskan bahwa Pendidikan merupakan faktor penting yang dapat berpengaruh terhadap pengetahuan individu. Semakin tinggi pendidikan seseorang maka semakin baik pula pengetahuannya (Lestari, 2015).

Berdasarkan hasil penelitian pada kelompok kontrol terjadi penurunan rata - rata pengetahuan responden setelah diberikan pendidikan kesehatan yakni sebesar 0,1. Menurut Ali (2015) pengetahuan bisa saja hilang kalau sesuatu hal itu tidak diminati dan dianggap tidak penting. Seseorang akan mau untuk mencoba sesuatu hal karena adanya minat, sehingga pengetahuan yang lebih dalam akan mudah diperoleh. Hal ini menjelaskan bahwa pada kelompok kontrol kurangnya minat responden terhadap informasi yang diberikan. Dalam memberikan informasi, media yang dipilih dan cara penyampaian informasi merupakan slalah satu faktor penting dalam meningkatkan pengetahuan individu (Induniasih \& Ratna, 2015). Pada kegiatan promosi kesehatan dengan menggunakan media dapat membantu peserta lebih mudah memahami materi dan pesan kesehatan yang diberikan (Nurmala, 2018).

Pada kelompok kontrol diberikan materi dalam WhatsApp Group sebanyak satu kali berupa tulisan dan gambar. Yensy (2020) menyatakan banyaknya chat yang masuk di WhatsApp grup dan menumpuk menjadi kendala responden dalam membaca materi yang diberikan. Tidak semua responden pada kelompok kontrol membaca materi yang diberikan pada saat materi dikirimkan, Ada yang membaca setelah dua hari bahkan setelah satu minggu materi tersebut di kirimkan. Hal ini mungkin dikarenakan tidak ada sesi diskusi melalui video call, untuk itu responden merasa tidak perlu segera membuka dan bisa membaca kapan saja materi tersebut. Menurut Yaumi (2018) dengan membaca hanya 10\% dan melihat $30 \%$ dari seluruh informasi yang diberikan 
maka dampaknya adalah responden tidak menyerap maksimal informasi yang diberikan.

Selanjutnya Berdasarkan hasil penelitian pada tabel 3 dapat dilihat bahwa rata - rata sikap responden sebelum diberikan intervensi pada kelompok intervensi $(31,06)$ sama dengan rata - rata sikap responden pada kelompok kontrol $(31,06)$. Hal ini jika dilihat dari karakteristik pekerjaan responden pada kelompok intervensi dan kelompok kontrol yang mana lebih dari separuh responden kelompok intervensi $(65,6 \%)$ dan responden kelompok kontrol $(56,3 \%)$ merupakan ibu rumah tangga. Menurut Gerungan (2010) selain faktor internal berupa pengetahuan dan pilihan individu, faktor eksternal berupa pekerjaan dan interaksi kelompok merupakan faktor yang berpengaruh terhadap individu dalam menentukan sikap. Dalam hal ini, dominan responden merupakan ibu rumah tangga yang lingkup interaksi kelompok dengan keluarga sendiri dan lingkungan sekitar, sehingga antara kelompok kontrol dan kelompok intervensi cenderung memiliki rata - rata sikap yang sama. Kesamaan nilai rata - rata sikap pada kedua kelompok merupakan hal yang wajar dikarenakan responden dikelompokkan dengan cara random sampling atau acak sehingga tidak ada intervensi apapun dalam pemilihan sampel.

Dalam penelitian ini media informasi yang digunakan dalam memberikan pendiddikan kesehatan sama, yakni mengirimkan berupa tulisan dan gambar kedalam WhatsApp Group. Namun terdapat perbedaan, pada metode pendidikan kesehatan yang diberikan antara kelompok kontrol dan kelompok intervensi. Purnama dan Jaka (2013) menyatakan kemampuan merubah sikap seseorang dapat di pengaruhi oleh penggunaan metode yang tepat dalam memberikan pendidikan kesehatan. Pada penelitian ini setelah dikirimkan materi berupa tulisan dan gambar pada kelompok intervensi dilanjutkan dengan diskusi melalui Video Call. Sementara pada kelompok kontrol tidak ada pengulangan materi dan tidak ada sesi diskusi. Yaumi (2018) menyatakan responden tidak akan dapat menyerap maksimal informasi yang diberikan hanya dengan membaca $10 \%$ dan melihat $30 \%$ dari seluruh informasi yang diberikan.

\section{Analisa Bivariat}

Berdasarkan hasil penelitian pada table 3 didapatkan pengaruh yang signifikan terhadap pengetahuan dan sikap pada kelompok intervensi yang diberikan Pendidikan kesehatan melalui WhatsApp Group dan Video Call sebanyak 3 kali dalam satu minggu dengan $p$ value pengetahuan 0,000 dan $p$ value sikap 0,000 . Hal ini berbeda pada kelompok kontrol dimana tidak terdapat pengaruh yang bermakna terhadap pengetahuan, sikap responden yang hanya diberikan materi Pendidikan kesehatan melalui whatsapp group sebanyak 1 kali dengan $p$ value pengetahuan 0,184 dan $p$ value sikap 0,325.

Hasil uji statistik menjelaskan bahwa pendidikan kesehatan menggunakan aplikasi whatsapp group dan video call memiliki pengaruh yang signifikan terhadap pengetahuan dan sikap ibu tentang imunisasi DPT dan KIPI di wilayah kerja Puskesmas Sungai Liuk Kota Sungai Penuh. Temuan pada penelitian ini sesuai dengan penelitian Hossain et al. (2021) menjelaskan bahwa penggunaan whatsapp mampu meningkatkan pengetahuan anggota grup mengenai imunisasi DPT. Hal yang serupa juga dijelaskan oleh penelitian lainnya, terdapat peningkatan pengetahuan responden tentang materi kesehatan setelah diberikan pendidikan kesehatan dengan whatsapp (Aziz et al., 2019; Coleman \& O'Connor, 2019; Ekadinata \& Widyandana, 2017; Pereira et al., 2020; Wicaksana et al., 2020).

Penggunaan whatsapp sebagai media pendidikan kesehatan yang diikuti dengan diskusi memungkinkan peningkatan interaksi antara peneliti dan anggota grup yang berada pada kelompok intervensi sehingga terjadi peningkatan pengetahuan posttest. Anggota grup dapat bertanya langsung ke peneliti ketika diskusi tentang imunisasi DPT tanpa harus bertemu tatap muka (Hossain et al., 2021). Adanya sesi diskusi dan pengulangan materi membuat peserta lebih mudah mengingat dengan informasi yang diberikan. Menurut Koring et al (2015) mengulang 2 kali dalam waktu 1 hari membuat peserta mampu mengingat selama satu minggu, dan mengulang 3 kali dalam satu minggu membuat daya tahan ingatan selama satu bulan. Selain itu, adanya ahli sebagai pendidik pada grup whatsapp maka akan meningkatkan minat learner dan memudahkan proses pembelajaran (KamelBoulos et al., 2016).

Namun, Hal ini tidak dialami oleh ibu yang berada di kelompok kontrol. Responden pada kelompok kontrol tidak mendapatkan penjelasan mengenai materi serta tidak ada sesi diskusi, sehingga menyebabkan adanya penurunan pengetahuan mereka saat postest. Pengetahuan yang benar tentang imunisasi DPT dan KIPI harus dimiliki oleh ibu. Pengetahuan dapat menjadi modal untuk memunculkan kesadaran ke arah yang lebih baik. Selanjutnya menjadi panduan dalam mengambil sikap dan berbuat.

Sikap merupakan respon perasaan berupa perasaan yang menunjukkan penerimaan atau perasaan yang menunjukkan penolakan terhadap stimulus atau objek. Sikap mempengaruhi praktik melalui proses pengambilan keputusan (Notoatmodjo, 2010). Ibu akan memiliki sikap mendukung (positif) tentang pemberian imunisasi DPT pada anaknya jika ia memandang imunisasi DPT berdampak baik bagi anaknya. Pada penelitian ini menjelaskan bahwa adanya pengaruh Pendidikan kesehatan terhadap sikap kelompok intervensi. Hal ini didukung oleh penelitian yang dilakukan Andriani et al. (2020) menjelaskan bahwa ada 
peningkatan sikap responden pada kelompok intervensi tentang imunisasi setelah mendapatkan pendidikan kesehatan menggunakan whatsapp. Pendidikan kesehatan melalui whatsapp mampu memperbaiki sikap ibu terhadap imunisasi DPT (Andriani et al., 2020). Hal yang serupa juga diungkapkan oleh penelitian lainnya, terdapat peningkatan sikap responden ke arah yang positif setelah diberikan perlakuan berupa pendidikan kesehatan menggunakan whatsapp (Gian, 2020; Salsabilla et al., 2018; Saraswati et al., 2019).

Namun hal ini bertolak belakang dengan penelitian yang dilakukan oleh Saleh, et al, (2020) yang menyatakan bahwa tidak ada pengaruh yang bermakna pada pengetahuan dan sikap responden setelah diberikan Pendidikan kesehatan melalui whatsapp. Hal serupa juga terjadi pada kelompok kontrol dalam penelitian ini yang mana tidak terjadi perubahan pengetahuan dan sikap setelah mendapatkan Pendidikan kesehatan melalui whatsapp. Hal ini disebabkan karena pada kelompok kontrol tidak ada sesi diskusi sehingga peneliti tidak dapat memastikan responden membaca materi yang telah diberikan atau hanya dilihat sekilas saja. Dari pembelajaran yang diberikan memberikan dampak $10 \%$ dari apa yang dibaca, dan $30 \%$ dari apa yang dilihat (Yaumi, 2018). Sehingga pada kelompok kontrol, kemampuan untuk menyerap informasi yang diberikan belum maksimal.

Secara konsep, pendidikan kesehatan merupakan proses pembelajaran yang bertujuan untuk meningkatkan interpretasi individu terhadap kesehatan (Notoatmodjo, 2010). Interpretasi ini nantinya akan mempengaruhi persepsi dan membantu dalam membuat keputusan yang selaras dengan tujuan kesehatan. Dalam penelitian ini, pendidikan kesehatan dilakukan agar ibu memiliki interpretasi yang baik tentang imunisasi DPT dan KIPI sehingga menaruh perhatian terhadap imunisasi DPT dan KIPI serta mendukung program imunisasi DPT.

Kelebihan dalam menggunakan Whatsapp sebagai media Pendidikan kesehatan memungkinkan tenaga kesehatan untuk berdiskusi dan berbagi informasi tentang imunisasi DPT ke banyak orang. Informasi dapat tersimpan untuk jangka waktu yang lama, sehingga masyarakat dapat membaca kembali informasi yang pernah dibagi oleh pendidik kesehatan (Alanzi et al., 2016; Astarcioglu et al., 2015; Khanna et al., 2015). Informasi tentang manfaat imunisasi DPT dan penanganan KIPI ketika sering dibaca maka akan mampu merubah keyakinan seseorang terhadap imunisasi DPT dari sikap menolak ke sikap menerima.

Kelebihan media yang digunakan dalam Pendidikan kesehatan yang diberikan adalah media sosial yang sangat familiar dikalangan masyarakat. Media sosial WhatsApp merupakan media yang populer mulai dari remaja hingga dewasa. Pemanfaatan media sosial whatsapp ini menjadi daya tarik tersendiri bagi responden. Selain menarik, materi yang diberikan dapat dibaca kembali oleh responden suatu saat dan tidak mudah hilang. Dengan adanya sesi diskusi melalui video call, mampu meningkatkan retensi ingatan responden terhadap informasi yang diberikan karena adanya pengulangan materi dan adanya diskusi. Sesuai teori yang menjelaskan Pendidikan kesehatan yang diberikan akan memiliki dampak, yakni $10 \%$ dari apa yang dibaca, $20 \%$ dari yang di dengar, 30\% dari yang dilihat, $50 \%$ dari yang di lihat dan didengar, $70 \%$ dari yang ditulis dan dikatakan, dan $90 \%$ dari yang dikatakan dan dilakukan. Selain itu, yang mempengaruhi hasil penelitian adalah durasi pemberian Pendidikan kesehatan, semakin sering maka akan semakin di ingat (Koring, et al, 2015)

Kemudian kekurangan penggunaan Whatsapp sebagai media Pendidikan kesehatan dapat terlihat pada kelompok kontrol. Pada kelompok kontrol diberikan materi sekaligus sebanyak satu kali berupa tulisan dan gambar dalam WhatsApp Group. Banyaknya responden kelompok kontrol yang membuka dan membaca materi beberapa hari setelah dikirimkan. Hal ini menunjukkan cara tersebut kurang menarik, selain itu peneliti tidak dapat mengontrol apakah materi tersebut dibaca atau hanya sekedar dibuka saja oleh responden. Yensy (2020) menyatakan banyaknya chat yang masuk di WhatsApp grup dan menumpuk menjadi kendala responden dalam membaca materi yang diberikan.

Hasil penelitian menjelaskan pengaruh positif pemanfaatan whatsapp sebagai media edukasi terhadap pengetahuan dan sikap ibu tentang imunisasi DPT dan penanganan KIPI jika hal tersebut disertai dengan diskusi. Hasil temuan ini dapat dijadikan bukti pendukung bagi petugas kesehatan untuk terus melaksanakan pendidikan kesehatan di masa pandemi covid-19 kepada masyarakat tentang imunisasi DPT dan KIPI walaupun dengan menggunakan media online whatsapp. Tujuannya adalah agar masyarakat tidak lagi menunjukkan sikap negatif terhadap program imunisasi DPT dan mampu secara mandiri mengatasi KIPI. Dengan demikian, angka cakupan imunisasi DPT dapat menjadi lebih tinggi.

Gaya hidup masyarakat saat ini tidak bisa dipisahkan dengan smartphone. Sebagian besar masyarakat usia remaja hingga dewasa telah menggunakan smartphone dan aplikasi media sosialnya seperti whatsapp. Kondisi ini menciptakan kemudahan bagi tenaga kesehatan untuk memberikan edukasi secara digital. Media sosial dapat dimanfaatkan sebagai alat untuk meningkatkan kesehatan masyarakat yang sulit dijangkau karena jarak ataupun karena kondisi pandemi Covid -19 yang mengharuskan untuk meminimalkan tatap muka dan kontak fisik. Saat ini dengan perkembangan teknologi seperti jaringan internet, masyarakat dapat mengakses segala bentuk informasi tentang imunisasi DPT. Hal tersebut membuka peluang kepada masyarakat untuk terpapar informasi yang tidak 
benar tentang imunisasi DPT, dan dapat mempengaruhi keputusan mereka dalam memberikan imunisasi DPT kepada anaknya. Dengan adanya grup whatsapp, pendidik kesehatan dapat senantiasa mempomosikan kesehatan berupa pengiriman pesan, gambar, atau artikel untuk mengarahkan masyarakat dan mengklarifikasi informasi-informasi keliru tentang imunisasi DPT yang telah dikonsumsi oleh masyarakat (Hossain, et al., 2011).

\section{SIMPULAN}

Ada pengaruh Pendidikan kesehatan dengan media whatsapp group terhadap pengetahuan dan sikap responden tentang imunisasi DPT dan KIPI pada kelompok intervensi. Selanjutnya pada kelompok kontrol tidak adanya pengaruh Pendidikan kesehatan menggunakan media whatsapp group terhadap pengetahuan dan sikap responden tentang imunisasi DPT dan KIPI.

\section{DAFTAR PUSTAKA}

Alanzi, T. M., Bah, S., Jaber, F., Alshammari, S., \& Alzahrani, S. (2016). Evaluation of a Mobile Social Networking Application for Glycaemic Control and Diabetes Knowledge in Patients with Type 2 Diabetes: A Randomized Controlled Trial Using WhatsApp. In Qatar Foundation Annual Research Conference Proceedings.

Ali. (2015). Tingkat Pengetahuan Tentang Bahaya Merokok Pada Siswa Kelas V SD Negeri Pucung Lor 02 Kecamatan Kroya Kabupaten Cilacap Tahun Pelajaran 2014/2015. e-Biomedik (eBm). 1, 34-45

Andriani, Y., Rusmil, K., \& Akbar, I. B. (2020). Measles-Rubella immunization health education using animated videos and text messages via WhatsApp. Berita Kedokteran Masyarakat, 36(3), 65-70.

Astarcioglu, M. A., Sen, T., Kilit, C., Durmus, H. I., Gozubuyuk, G., Kalcik, M., \& Amasyali, B. (2015). Time-to-reperfusion in STEMI undergoing interhospital transfer using smartphone and WhatsApp messenger. The American Journal of Emergency Medicine, 33(10), 1382-1384.

Azreena, C. A. M. Z., Nor Afiah, and A. M. Rosliza. 2018. "Predictors for Inadequate Knowledge and Negative Attitude towards Childhood Immunization among Parents in Hulu Langat, Selangor, Malaysia.” Malaysian J. Public Heal. Med 18(1):102-12.

Aziz, A. R., Kosasih, C. E., \& Lukman, M. (2019). Pengaruh pemberian informasi kesehatan berbasis aplikasi whatsapp terhadap remaja di sekolah menengah atas. Al-Asalmiya Nursing: Journal of Nursing Sciences, 8(1), 8-16.
Coleman, E., \& O'Connor, E. (2019). The role of WhatsApp ${ }^{\circledR}$ in medical education; a scoping review and instructional design model. BMC Medical Education, 19(1), 1-13.

Dinas Kesehatan Kota Sungai Penuh. 2021. Bidang Pengendalian dan Pencegahan Penyakit.

Ekadinata, N., \& Widyandana, D. (2017). Promosi kesehatan menggunakan gambar dan teks dalam aplikasi WhatsApp pada kader posbindu. Berita Kedokteran Masyarakat, 33(11), 547.

Gerungan, WA. (2010). Psikologi Sosial. Bandung: PT. Refika Aditama.

Gian, G. G. (2020). Pengaruh Edukasi Gizi Menggunakan Media Podcast Dan Whatsapp Terhadap Perubahan Pengetahuan, Sikap Dan Tindakan Dalam Pencegahan Anemia Pada Siswi SMAN 10 Padang Tahun 2020. Universitas Andalas.

Hossain, I., Mugoya, I., Muchai, L., Krudwig, K., Davis, N., Shimp, L., \& Richart, V. (2021). Blended Learning Using Peer Mentoring and WhatsApp for Building Capacity of Health Workers for Strengthening Immunization Services in Kenya. Global Health: Science and Practice, 9(1), 2012015.

Hockenberry, Wilson, \& Rodgers. 2019. Wong's Nursing Care of infants and Children (11th ed). Canada: Elsevier

Induniasih, and W. Ratna. 2015. Promosi Kesehatan: Pendidikan Kesehatan Dalam Keperawatan. Yogyakarta: Pustaka Baru Press.

Koring, M., Richert, J., Lippke, S., Parschau, L., Reuter, T., \& Schwarzer, R. 2015. Synergistic Effects Of Plsnning and Self-Efficacy on physical Activity. Health Education \& Behavior, 45(Pf 10). http://doi.org/10.1177/1090198111417621

KamelBoulos, M. N., Giustini, D. M., \& Wheeler, S. (2016). Instagram and WhatsApp in health and healthcare: An overview. Future Internet, 8(3), 37.

Kemenkes RI. 2020. Profil Kesehatan Indonesia;Infodatin. Jakarta:Direktur Jenderal Pengendalian Penyakit dan Penyehatan Lingkungan.

Khanna, V., Sambandam, S. N., Gul, A., \& Mounasamy, V. (2015). "WhatsApp" ening in orthopedic care: a concise report from a 300-bedded tertiary care teaching center. European Journal of Orthopaedic Surgery \& Traumatology, 25(5), 821-826.

Kemenkes RI. 2018b. Riset Kesehatan Dasar. Jakarta: Kemenkes RI.

Kemenkes RI. 2020. Profil Kesehatan Indonesia;Infodatin. Jakarta: Direktur Jenderal Pengendalian Penyakit dan Penyehatan Lingkungan.

Kemenkes RI. (2021). Pusdatin. Jakarta: Kemenkes RI. Konwea, P,E., Funmilayo A, D., Seyi, E,O. 2018. 
Determinants Of Compliance With Child Immunization Among Mothers Of Children Under Five Years Of Age In Ekiti State, Nigeria. Journal of Health Research.229-236

Lestari, T. 2015. Kumpulan Teori Untuk Kajian Pustaka Penelitian Kesehatan. Yogyakarta: Nuha Medika.

Lim, H. W. Y. S. S., J. Amar-Singh, H. Netia, N. A. Rahmat, M. Y. Mustafa, R. Fatimah-Sham, S. Rahman, C. H. Itam, Chan, and M. S. N. Julia. 2016. "Exploring Immunisation Refusal by Parents in the Malaysian Context." Cogent Med 3(1):1142410.

Mulyani, Sri dan Andi Subandi. 2020. Efektifitas Pendidikan Kesehatan Melalui Group Whatsapp Reminder Berkala Dengan Metode Ceramah Terhadap Pemberian ASI Ekslusif Pada Inu Pasca Sectio Sesarea. Jurnal Ilmiah Ilmu Terapan Universitas Jambi. 4(2), 187-203

Nurmala, I. 2018. Promosi Kesehatan. Surabaya: Airlangga University Press.

Notoatmodjo, S. (2010). Promosi kesehatan, teori dan aplikasi (Revisi). Rineka Cipta.

Pereira, A. A. C., Destro, J. R., Bernuci, M. P., Garcia, L. F., \& Lucena, T. F. R. (2020). Effects of a WhatsApp-Delivered Education Intervention to Enhance Breast Cancer Knowledge in Women: Mixed-Methods Study. JMIR MHealth and UHealth, 8(7), e17430.

Purnama dan Jaka. (2013). Media dan Metode Penyuluhan yang Efektif bagi Penyuluh Kesehatan. Jawa Tengah: Badan Pendidikan dan Pelatihan.

Saleh, N,MH., Eman, HM, R., Abdel, H,E., Heba, E, M. (2020). Effect of an Educational Program Via Whatsapp on Knowledge, attitude, and practices of elderly toward Covid-19. Egyptian Nursing Journal. 17(3), 147

Salsabilla, D. A., Subaris, H., \& Werdani, K. E. (2018). Pengaruh Pendidikan Kesehatan Tentang Sadari Melalui Media Line Messenger Dan Whatsapp Messenger Terhadap Pengetahuan Dan Sikap Remaja Putri. Universitas Muhammadiyah Surakarta.

Saraswati, P. S., Tasnim, T., \& Sunarsih, S. (2019). Pengaruh Media Whatsapp Dan Leaflet Terhadap Perilaku Pemeriksaan Payudara Sendiri Pada Siswi Sekolah Menengah Atas Di Kota Kendari. Al-Sihah: The Public Health Science Journal, 11(2), 12-17.

Sari, Dewi Nur Intan, Sri Wahyu Basuki, and N. Juni Triastuti. 2016. "Hubungan Pengetahuan Ibu Dengan Kelengkapan Imunisasi Dasar Bayi Di Wilayah Kerja Puskesmas Bendo Kabupaten Magetan." Biomedika 8(2):1-8.

Verulava, T., M. Jaiani, A. Lordkipanidze, R. Jorbenadze, and B. Dangadze. 2019. 'Mothers'
Knowledge and Attitudes towards Child Immunization in Georgia." The Open Public Health Journal 12(1):1-12.

Wicaksana, B. Y., Sajidin, M., \& Triwibowo, H. (2020). Pengaruh pendidikan kesehatan dengan media whatsapp group terhadap pengetahuan pencegahan penularan tb. Kesmas: Jurnal Kesehatan Masyarakat Nasional (National Public Health Journal), 5(1), 8-13.

Yaumi, Muhammad. (2018). Media dan Teknologi Pembelajaran. Makasar: Prenadamedia Group.

Yensy, Nurul Astuti. (2020). Efektifitas Pembelajaran Statistika Matematika Melalui Media Whatsapp Group di Tinjau dari HAsil Belajar Mahasiswa (Masa Pandemi Covid-19). Jurnal Pendidikan Matematika Raflesia. 5(2),65-74

Yuniarti dan Yuni Ansi Ermitha. 2020. Pengaruh Pendidikan Kesehatan Melalui Media Leaflet dan Whatsapp terhadao Peningkatan Pengetahuan Ibu Menyusui. Mahakam Midwifery Journal. 5(1), 1226

Yustanta dan Ikhrima. 2021. "The Timeliness of Basic Immunization in Infants Related To the Knowledge About Covid-19". Procedia of social sciences and Humanities 